\title{
Curcumin Loaded Dendrimers Specifically Reduce Viability of Glioblastoma Cell Lines
}

\author{
John Gallien 1,2,3, Bhairavi Srinageshwar 1,2,3 (-), Kellie Gallo 1,3,4 Gretchen Holtgrefe 5 , Sindhuja Koneru 1,2, \\ Paulina Sequeiros Otero 1,2,3, Catalina Alvarez Bueno ${ }^{1,2}$, Jamie Mosher ${ }^{5}$, Alison Roh ${ }^{5}$, D. Stave Kohtz ${ }^{2,4}$, \\ Douglas Swanson ${ }^{5}$, Ajit Sharma ${ }^{5}$, Gary Dunbar ${ }^{1,2,6,7}$ and Julien Rossignol ${ }^{1,2,3, *(\text { C) }}$
}

1 Field Neurosciences Institute Laboratory for Restorative Neurology, Central Michigan University, Mt. Pleasant, MI 48859, USA; galli2j@cmich.edu (J.G.); srina1b@cmich.edu (B.S.); gallo1k@cmich.edu (K.G.); koner1s@cmich.edu (S.K.); otero1p@cmich.edu (P.S.O.); bueno1c@cmich.edu (C.A.B.); dunba1g@cmich.edu (G.D.)

2 Program in Neuroscience, Central Michigan University, Mt. Pleasant, MI 48859, USA; kohtz1d@cmich.edu

3 College of Medicine, Central Michigan University, Mt. Pleasant, MI 48859, USA

4 Biochemistry, Cellular and Molecular Biology Program, Central Michigan University, Mt. Pleasant, MI 48859, USA

5 Department of Chemistry and Biochemistry, Central Michigan University, Mt. Pleasant, MI 48859, USA; holtg1ge@cmich.edu (G.H.); jlmosher23@gmail.com (J.M.); alroh@umich.edu (A.R.); swans1d@cmich.edu (D.S.); sharm1a@cmich.edu (A.S.)

6 Field Neurosciences Institute, St. Mary's of Michigan, Saginaw, MI 48604, USA

7 Department of Psychology, Central Michigan University, Mt. Pleasant, MI 48859, USA

* Correspondence: rossi1j@cmich.edu

check for updates

Citation: Gallien, J.; Srinageshwar, B.; Gallo, K.; Holtgrefe, G.; Koneru, S.; Otero, P.S.; Bueno, C.A.; Mosher, J.; Roh, A.; Kohtz, D.S.; et al. Curcumin Loaded Dendrimers Specifically Reduce Viability of Glioblastoma Cell Lines. Molecules 2021, 26, 6050. https: / / doi.org/10.3390/ molecules 26196050

Academic Editor: Chiara Porro

Received: 20 August 2021

Accepted: 30 September 2021

Published: 6 October 2021

Publisher's Note: MDPI stays neutral with regard to jurisdictional claims in published maps and institutional affiliations.

Copyright: (c) 2021 by the authors. Licensee MDPI, Basel, Switzerland. This article is an open access article distributed under the terms and conditions of the Creative Commons Attribution (CC BY) license (https:// creativecommons.org/licenses/by/ $4.0 /)$.
Abstract: Glioblastoma (GB) is a deadly and aggressive cancer of the CNS. Even with extensive resection and chemoradiotherapy, patient survival is still only 15 months. To maintain growth and proliferation, cancer cells require a high oxidative state. Curcumin, a well-known anti-inflammatory antioxidant, is a potential candidate for treatment of GB. To facilitate efficient delivery of therapeutic doses of curcumin into cells, we encapsulated the drug in surface-modified polyamidoamine (PAMAM) dendrimers. We studied the in vitro effectiveness of a traditional PAMAM dendrimer (100\% amine surface, G4 $\left.\mathrm{NH}_{2}\right)$, surface-modified dendrimer (10\% amine and $90 \%$ hydroxyl-G4 90/10-Cys), and curcumin (Cur)-encapsulated dendrimer (G4 90/10-Cys-Cur) on three species of glioblastoma cell lines: mouse-GL261, rat-F98, and human-U87. Using an MTT assay for cell viability, we found that G4 90/10-Cys-Cur reduced viability of all three glioblastoma cell lines compared to non-cancerous control cells. Under similar conditions, unencapsulated curcumin was not effective, while the non-modified dendrimer $\left(\mathrm{G} 4 \mathrm{NH}_{2}\right)$ caused significant death of both cancerous and normal cells. By harnessing and optimizing the components of PAMAM dendrimers, we are providing a promising new route for delivering cancer therapeutics. Our results with curcumin suggest that antioxidants are good candidates for treating glioblastoma.

Keywords: PAMAM dendrimers; curcumin; toxicology; nano-molecule; therapy; glioblastoma; cancer

\section{Introduction}

Glioblastomas (GB) are among the most common and malignant brain tumors of the central nervous system, impacting more than 10,000 people in the United States each year with a median survival rate of approximately 15 months in patients receiving treatment [1]. Treatment typically includes a combination of radiation, neurosurgery, and chemotherapy with temozolomide (TMZ). However, despite great advances in these treatments, the prognosis for GB patients has remained relatively stable over the last three decades, with less than $5 \%$ of GB patients living past 5 years, and no reports of cured patients [2]. Outcomes 
remain poor, due to resistance to treatment and a lack of other targeted therapies [3]. Furthermore, translational efficacy of therapeutics moving from preclinical to clinical use has been particularly poor for glioblastoma.

Temozolomide is the current gold standard of treatment for GB, typically given concomitantly with radiation [4]. However, in nearly $50 \%$ of patients this drug is ineffective, largely due to drug resistance linked to a genetic predisposition and methylation of the MGMT gene ( $\mathrm{O}^{6}$-methylguanine methyltransferase), and/or lack of a DNA repair pathway in GB cells [5]. Due to the highly resistant, infiltrative, and aggressive nature of this disease, new treatments are essential to improve the prognosis of current and future patients.

Curcumin (diferuloylmethane) is a polyphenol isolated from the rhizome of the C. longa plant that has been shown to have anticancer effects, primarily due to its antioxidant and anti-inflammatory properties [6]. Curcumin has been studied for the treatment of many diseases including Alzheimer's disease [7], diabetes [8], hepatitis, and a variety of different cancers, including pancreatic cancer, breast cancer and glioblastoma [9-12]. While initial studies using curcumin in vitro and with rodent models in vivo showed great promise, human clinical trials repeatedly failed to show the same therapeutic value even at doses as high as $8 \mathrm{~g}$ per day [13].

There are three major pitfalls to the use of curcumin that prevent its therapeutic actions: poor bioavailability, rapid clearance from the body, and rapid metabolism [14]. Previous attempts to facilitate systemic delivery of curcumin, such as packaging in liposomes, have been largely unsuccessful, due to the poor stability of liposomes and the tendency of their external lipid membrane to conjugate to other lipids in the body [15]. Curcumin alone can cross the blood brain barrier (BBB) in small amounts, but packaging curcumin inside a vehicle such as a liposome has great potential, but their size often prevented them from crossing the intact $\mathrm{BBB}$. While the BBB is disrupted in glioblastoma, the tumor environment and poor vascularization around the tumor prevent even some of the smallest particles from reaching the inner core of a tumor mass [16]. Other novel vehicles are composed of organic compounds which lack solubility in water. Therefore, vehicles that are capable of delivering therapeutics, while still maintaining a size small enough to penetrate the blood brain tumor barrier (BBTB), are needed.

Nano-molecules have been used for almost a century in industrial fields such as construction, agriculture, and carbon-based fuels; more recently, some have been adapted for use in the biomedical sciences [17]. First conceptualized in the late 1970s, hyperbranched "starburst polymers" or "dendrimers" were first synthesized in the early 1980s [18]. Dendrimers differ from other monomers and oligomers in their highly dendritic branching density and functional terminal end groups. Their small size $(1-10 \mathrm{~nm})$ and the potential to manipulate and control separate components of a dendrimer, make dendrimers suitable candidates for several biomedical applications, including delivery of genes, encapsulated non-soluble molecules, and drugs conjugated to the surface of dendrimers $[19,20]$.

Polyamidoamine (PAMAM) dendrimers are comprised of a core, a branched interior structure, and functional surface groups. Each of these components can be modified to yield dendrimers with a unique phenotype tailored to specific therapeutic actions. Traditional fourth generation PAMAM dendrimer with $100 \% \mathrm{NH}_{2}$ surface, which exist as protonated positively charged amines $\left(\mathrm{NH}_{3}{ }^{+}\right)$at physiological $\mathrm{pH}$, are highly toxic to cells [21]. Therefore, our lab has developed a reproducible de novo method of synthesizing fourth-generation dendrimers (G4) with a modified surface containing fewer positively charged amines resulting in reduced cellular toxicity. One of the current formulations is a G4 dendrimer with $90 \%$ of the amine surface replaced with neutral hydroxyl $(\mathrm{OH})$ groups referred to as G4 90/10-Cys (Figure 1). 


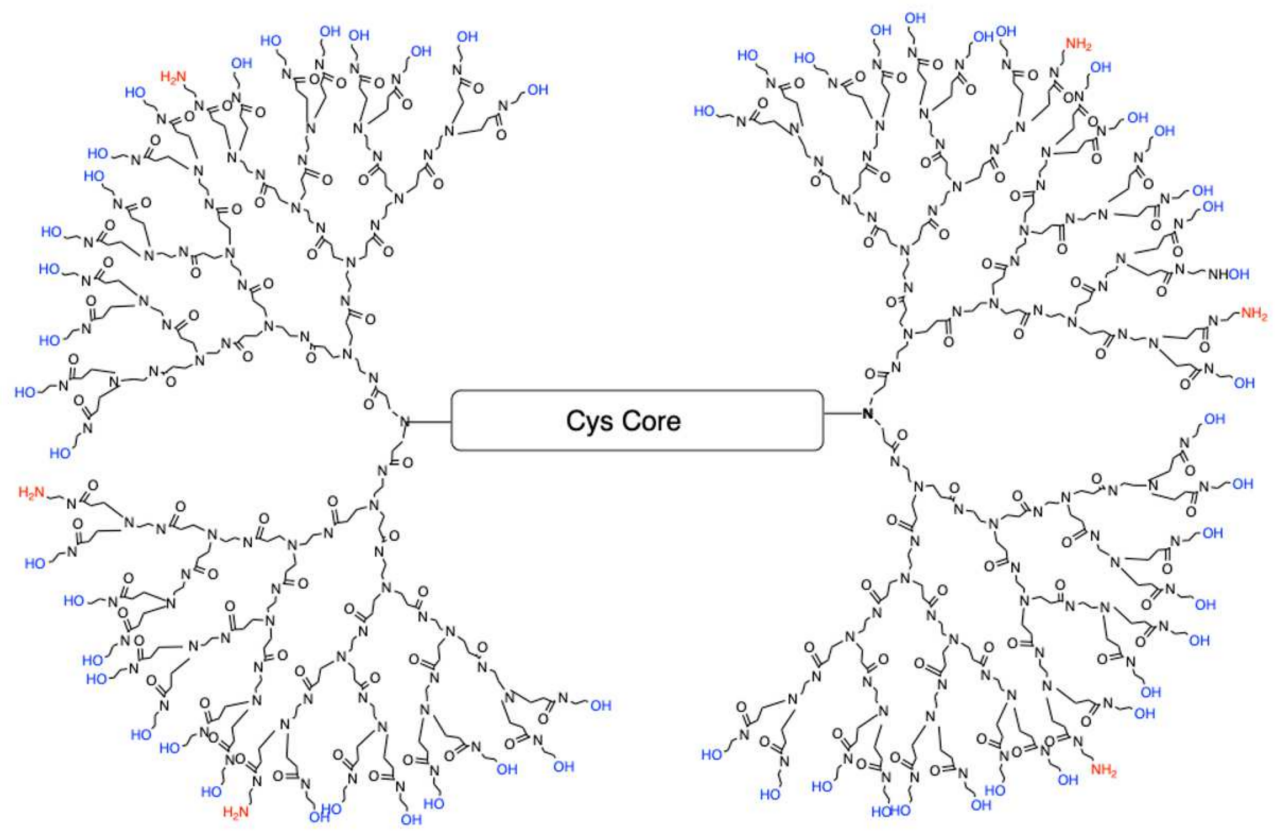

Figure 1. Configuration of G4 90/10-Cys in which $90 \%$ of the surface groups are-OH (blue), leaving only $10 \%$ as $\mathrm{NH}_{2}$ (red). The core is cystamine.

The core of G4 90/10 is composed of cystamine, with a disulfide bond holding together the two halves of the dendrimer, or "dendrons." As shown in Figure 2, upon entering a cell, glutathione or other reducing agents reduce and break the disulfide bond, thus splitting the dendrimer into two dendrons [22], facilitating cargo release (e.g., curcumin) into the interior of the cell.

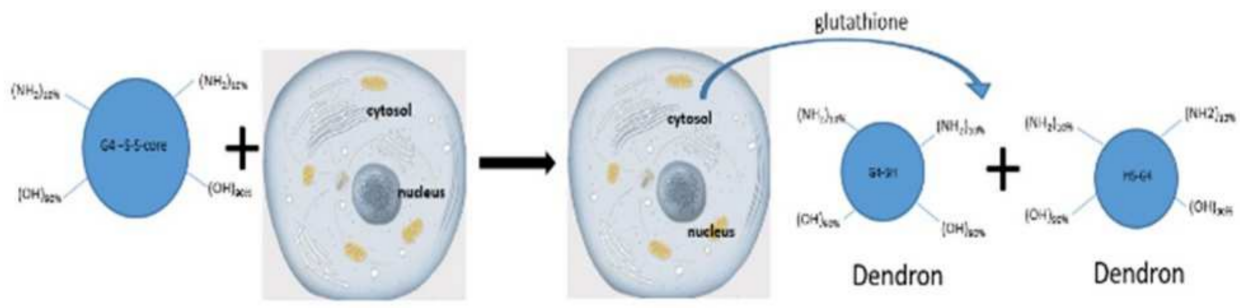

Cystamine dendrimer in oxidized form (-S-S-)

Cystamine dendrimer splits to form dendrons (reduced form; - $\mathrm{SH}$ SH-) having anti-inflammatory property

Figure 2. Dendrimer splitting. Upon entering the cell through non-mediated endocytosis, the dendrimer's core gets reduced from -S-S- to -SH, splitting the dendrimer into two "dendrons".

Recent studies suggest that the polyphenol curcumin, in addition to its many anticancer effects, may also function as a "drug resistance preventer" in certain types of cancers, including glioblastoma [23]. Due to its potential therapeutic value, we created a novel dendrimer/curcumin formulation (G4 90/10-Cys-Cur) for use in this study. The G4 90/10-Cys-Cur has a ratio of 10:1 (w/w) dendrimer to curcumin. On a mole basis, the ratio is four curcumin per dendrimer. The curcumin-encapsulated dendrimer may be used as a treatment, themselves, or possibly as an adjunctive treatment to those resistant to TMZ or other chemotherapy drugs.

A common practice in drug development is to investigate the effectiveness of treatments in lower forms of mammals before moving to non-human primates and humans as test subjects. The guidelines for multiple dosing toxicity assessment were developed in 1940, which included multispecies testing as a basic requirement for new drugs, prior to clinical applications [24]. These multispecies preclinical drug testing approaches were 
further encouraged by study reports about various pharmacological responses in different species to the same drug. Therefore, to account for multispecies variability, we tested our dendrimer treatments on U87-human, F98-rat, and GL261-mouse glioblastoma cell lines, and healthy control cell lines using HEK 293, rat mesenchymal stem cells (MSCs), and mouse-MSCs.

The goal of the study was to develop modified PAMAM dendrimers of different formulations and encapsulating curcumin as potential treatment for glioblastoma in rodent and non-rodent cell lines. Efficacy and specificity of treatment toward cancer cells was assessed using 3-(4,5-dimethylthiazol-2-yl)-2,5-diphenyltetrazolium bromide (MTT) toxicity assays. Although qualitative assessments of cell death included observations of floating cells, accumulation of cell fragments and precipitated material, change in media color, etc., the MTT assay was used to quantify the cell death. The MTT is commonly used to determine general toxicity profiles for new pharmacological therapies.

\section{Results}

\subsection{Dendrimer Characterization}

Acidic PAGE (Figure 3) was performed to confirm differences in the surface charge composition of G4 90/10-Cys (lane 2) compared to G4 $\mathrm{NH}_{2}$ (lane 1). Under these conditions, the dendrimers migrate based on their charge density. Since the size (molecular weight) of G4 90/10-Cys and G4 $\mathrm{NH}_{2}$ are quite similar $(\sim 14,300 \mathrm{kDa})$, their migration towards the cathode depends on their surface charge. As expected, $\mathrm{G}_{4} \mathrm{NH}_{2}$, which has $100 \%$ amines, migrates much faster than the G4 90/10-Cys with 10\% surface amines.

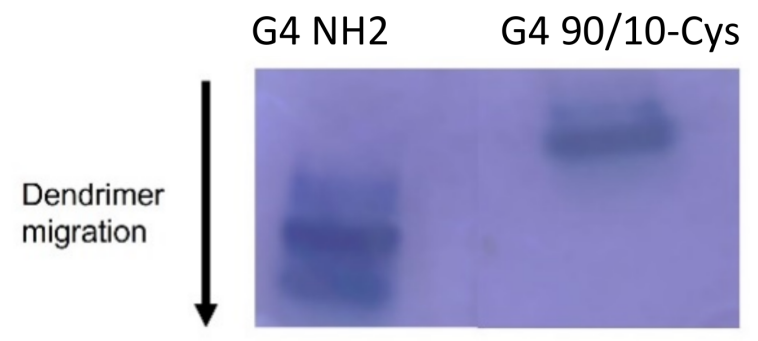

Figure 3. Migration of $\mathrm{G}_{4} \mathrm{NH}_{2}$ and $\mathrm{G} 490 / 10-\mathrm{Cys}$ in PAGE gel. From the migration pattern, the dendrimer with $100 \%$ amine migrated farthest (lane 1), followed by the dendrimer with $10 \%$ amines (lane 2). The migration pattern under acidic conditions reflects the concentration of amines on the dendrimer surface.

Reverse phase high performance liquid chromatography (RP-HPLC) of G4 90/10-Cys shows that it is a relatively pure product (Figure 4), with a retention time of $10.1 \mathrm{~min}$ [25].

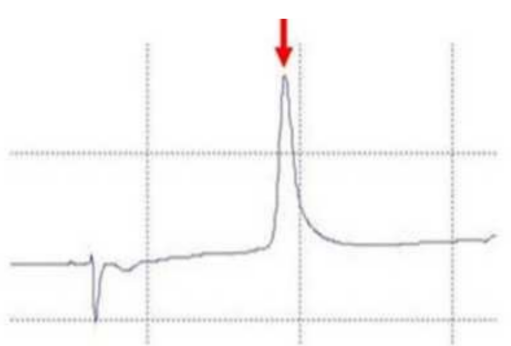

$\mathrm{G} 4-90 / 10$ at $1 \mathrm{mg} / \mathrm{mL}$

Figure 4. RP-HPLC of G4 90/10-Cys. The peak (red arrow) observed during RP-HPLC confirms that the synthetized dendrimer is pure and homogeneous.

\subsection{Reduction of G4 90/10-Cys Dendrimers in the Presence of Glutathione}

To confirm that the G4 90/10-Cys dendrimers were reduced by glutathione $(0.6 \mathrm{mg} / \mathrm{mL}$ and $1.2 \mathrm{mg} / \mathrm{mL}$ ) compared to a control, the splitting of the dendrimer was assessed. As 
shown in Figure 5, the dendrimers split in the presence of glutathione (Figure 5). The bottom dark band (that migrates faster towards the cathode-Figure 5 in lane 2 and 3) represents the dendrimer (dendrons) after the parent dendrimer is treated with $0.6 \mathrm{mg} / \mathrm{mL}$ glutathione (30 min incubation at room temperature). The faint band that co-migrates with the dendron observed in lane 1 may be the result of natural reduction after synthesis.

Lane 1

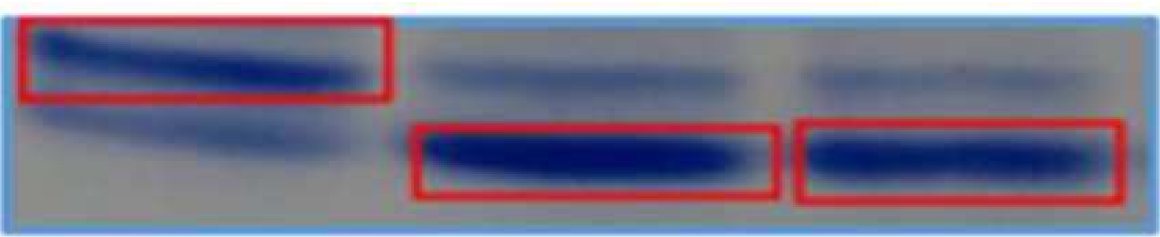

Lane 2

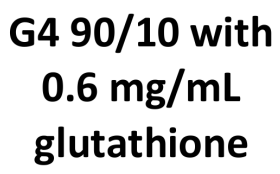

Lane 3

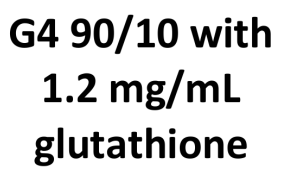

Figure 5. Splitting of G4 90/10 in the presence of glutathione (GSH): Splitting of cystamine dendrimer in the presence of glutathione (GSH): Acid page electrophoresis: Lane 1 contains purified dendrimer; lane 2 contains dendrimer + GSH $(0.6 \mathrm{mg} / \mathrm{mL})$; and lane 3 contains dendrimer $+\mathrm{GSH}$ $(1.2 \mathrm{mg} / \mathrm{mL})$. The top band represents the intact dendrimer while the bottom band represents the reduced dendrimer. The presence of a small amount of reduced dendrimer in lane one is likely the result of reduction during storage. Lanes 2 and 3 show the reduction of the dendrimer in the presence of GSH. It can be clearly seen from lanes 2 and 3 (bottom right band) that glutathione effectively reduces the dendrimer under these conditions.

\subsection{Curcumin Release from G4 90/10-Cys}

UV-visible spectra of the dendrimer and encapsulated curcumin are shown in Figure 6. Curcumin in water (grey line) shows a very small peak at around $420 \mathrm{~nm}$ (barely visible on Figure 6) due to its extremely poor aqueous solubility. Cyclodextrins are cyclic carbohydrates that are also often used to solubilize poorly soluble drugs and other chemicals in water. Curcumin encapsulated in 2-hydroxylpropyl cyclodextrin (orange line) shows a peak at $430 \mathrm{~nm}$. The peak shifted to around $420 \mathrm{~nm}$ when curcumin was encapsulated within the dendrimer (blue line). The dendrimer G4 90/10-Cys (yellow line) has a peak at $280 \mathrm{~nm}$ but does not show any absorbance above $330 \mathrm{~nm}$.

The release kinetics of curcumin encapsulated in G4 90/10-Cys is shown in Figure 7. Rapid release was observed in PBS at room temperature over a 4-h period followed by a slower release over the next few days. The initial release (zero-order kinetics; slope $=0.0033$; $\left.\mathrm{R}^{2}=0.95\right)$ may be due to curcumin that is weakly bound to the dendrimer surface or encapsulated within the superficial cavities of the nano-molecule. The second slow-release phase (zero-order kinetics; slope $=0.0003 ; R^{2}=0.97$ ) is likely to be from the curcumin encapsulated within the deeper cavities of the G4 90/10-Cys dendrimer.

\subsection{Effects of G4 90/10-Cys and G4 90/10-Cys-Cur on Different Glioblastoma Cell Lines}

Three curcumin-encapsulated dendrimer formulations were tested on various glioblastoma (U87, F98, GL261) and control (HEK 293, Rat MSC, Mouse MSC) cells. The formulations are shown in Table 1. 


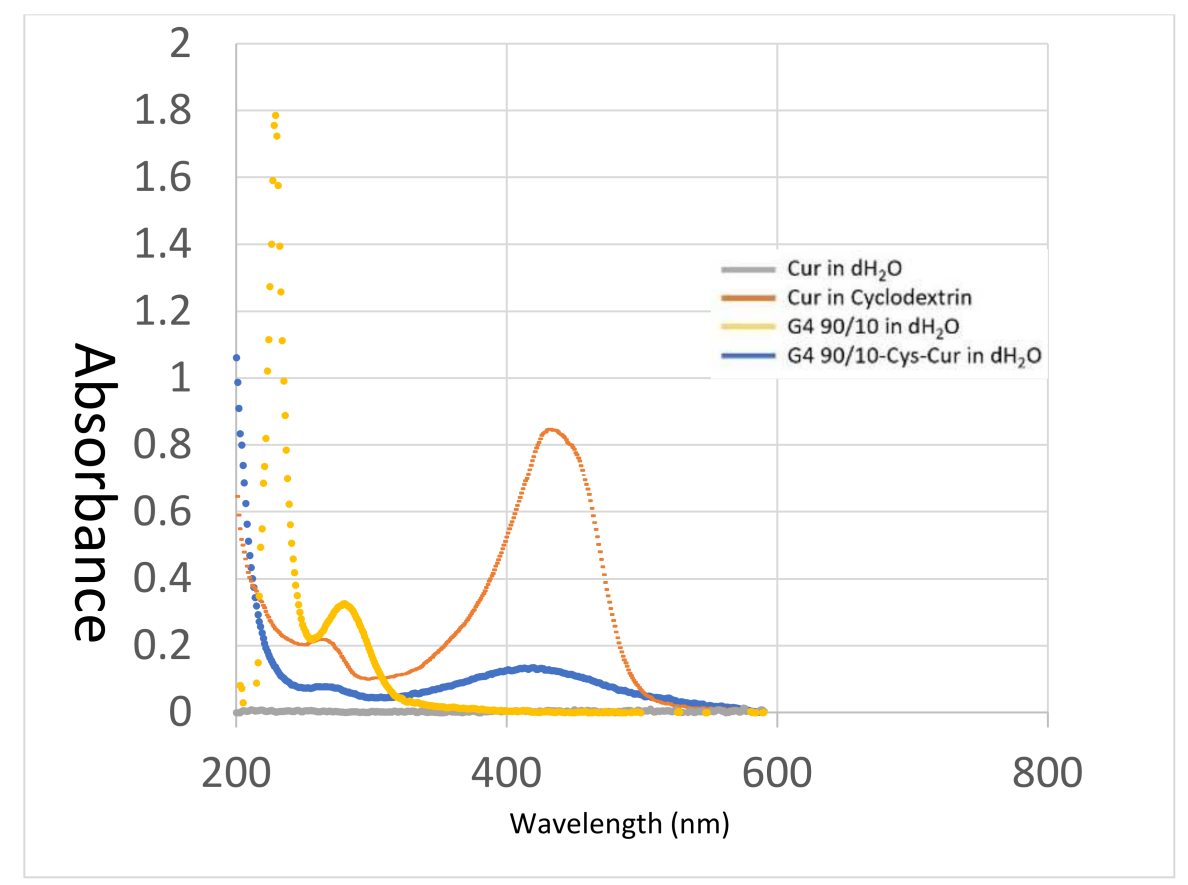

Figure 6. UV-Visible Spectroscopy of encapsulated curcumin. Absorbance spectra of Cur in water ( 1 $\mu \mathrm{g} / \mathrm{mL}$-grey line), Cur in cyclodextrin (orange line), G4 90/10-Cys in water (10 mg/mL-yellow line) and G4 90/10-Cys-Cur complexes weight ratio $(w / w)$ of D to Cur at 10:1 in distilled water (blue line).

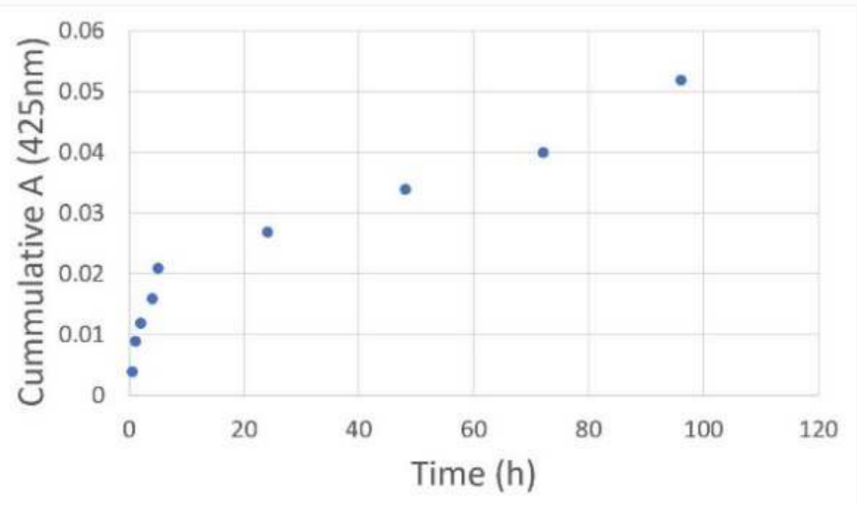

Figure 7. Release kinetics of the encapsulated curcumin: G4 90/10-Cys-Cur was placed in a dialysis tubing $(3.5 \mathrm{kDa})$ and dialyzed against methanol at a constant speed. Samples of the dialysate were taken at various time intervals and their absorbance values at $425 \mathrm{~nm}$ were obtained. After removal of each sample of dialysate, fresh PBS was added to maintain the original volume.

Table 1. G4 90/10-Cys encapsulated with varying amounts of curcumin.

\begin{tabular}{|c|c|c|}
\hline Formulation & [G4 90/10-Cys], mg/mL & [Curcumin], $\mathrm{mg} / \mathrm{mL}$ \\
\hline $\mathrm{F} 1$ & 0.2 & 0.02 \\
\hline F2 & 0.6 & 0.06 \\
\hline F3 & 1.0 & 0.1 \\
\hline
\end{tabular}

Curcumin (made from stock dilutions dissolved in DMSO) did not show any effect on the viability of any cell line tested. At the highest dose of curcumin, $(0.1 \mathrm{mg} / \mathrm{mL})$, there was 100\% cell viability after $24 \mathrm{~h}$ incubation of all cell lines (U87, GL261, F98 and 
non-cancerous cells). In all our results, we compared the viability of cell lines treated with different formulations (Table 1) against untreated cell lines.

2.4.1. Effect of Curcumin Conjugated Dendrimers on Human-Derived Cancer Cells (U87) and Human Kidney Control Cells (HEK 293)

For HEK 293: G4 90/10-Cys did not affect cell viability at any dose; $\mathrm{D}=0.02 \mathrm{mg} / \mathrm{mL}$, $p=0.68, \mathrm{D}=0.06 \mathrm{mg} / \mathrm{mL}, p=0.46 . \mathrm{D}=1.0 \mathrm{mg} / \mathrm{mL} p=0.54$. For G4 90/10-Cys-Cur, cell viability was lost at the highest dose; $\mathrm{D}=0.02 \mathrm{mg} / \mathrm{mL}, p=0.0151, \mathrm{D}=0.06 \mathrm{mg} / \mathrm{mL}, p=0.12$, $\mathrm{D}=1.0 \mathrm{mg} / \mathrm{mL}, p=0.02$. For the cell treated with $\mathrm{NH}_{2}$, cell viability was significantly lost at every dose; $p=0.0001$.

As shown in Figure 8 and Tables 2 and 3, all formulations of encapsulated curcumin, G4 90/10-Cys-Cur dendrimers (F1-F3), reduced viability of the cancerous cells (U87) compared to Curcumin alone. It is interesting to note that the F3 formulation was only toxic to HEK 293. G4 90/10-Cys by itself showed negligible effects on either the cancer cells or healthy cells, while $\mathrm{G} 4 \mathrm{NH}_{2}$ showed significant killing of both cancer and normal cells.

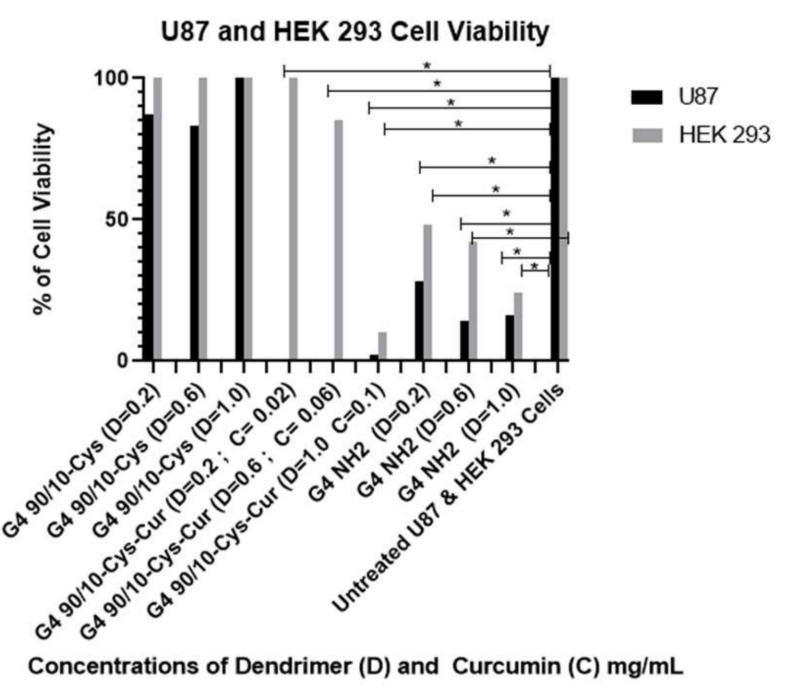

Figure 8. Viability of U87 and non-cancerous HEK 293 control cell after 24 h treatment with G4 90/10Cys, G4 90/10-Cys-Cur, and G4 NH 2 . G4 90/10-Cys had no significant effect on reducing cell viability, but in fact increased viability at the two higher doses. For U87: G4 90/10-Cys; D = $0.02 \mathrm{mg} / \mathrm{mL}$, $p=0.97, \mathrm{D}=0.06 \mathrm{mg} / \mathrm{mL}, p=0.0009 . \mathrm{D}=1.0 \mathrm{mg} / \mathrm{mL} p=0.0001$. For G4 90/10-Cys-Cur $p<0.0001$ for all three doses. For the cell treated with $\mathrm{NH}_{2}$, cell viability was significantly lost at every dose; $\mathrm{D}=0.02 \mathrm{mg} / \mathrm{mL}, p=0.0038, \mathrm{D}=0.06 \mathrm{mg} / \mathrm{mL}, p=0.0001, \mathrm{D}=1.0 \mathrm{mg} / \mathrm{mL}, p=0.0001 .{ }^{*} p<0.05$.

Table 2. Effect of F1, F2 and F3 on U87 cells.

\begin{tabular}{|c|c|c|c|c|c|}
\hline Formulation & Dendrimer & [Dendrimer] $\mathrm{mg} / \mathrm{mL}$ & [Curcumin] mg/mL & Cell Viability (\%) & $p$ Value \\
\hline F1 & G4 90/10-Cys & 0.2 & 0.02 & 0 & $<0.0001$ \\
\hline F2 & G4 90/10-Cys & 0.6 & 0.06 & 0 & $<0.0001$ \\
\hline F3 & G4 90/10-Cys & 1 & 0.1 & 2 & $<0.0001$ \\
\hline Dendrimer control & G4 90/10-Cys & 0.2 & 0 & 87 & 0.97 \\
\hline Dendrimer control & G4 90/10-Cys & 0.6 & 0 & 83 & 0.0009 \\
\hline Dendrimer control & G4 90/10-Cys & 1 & 0 & 100 & $<0.0001$ \\
\hline Dendrimer control & $\mathrm{G} 4 \mathrm{NH}_{2}$ & 0.2 & 0 & 28 & 0.0038 \\
\hline Dendrimer control & $\mathrm{G} 4 \mathrm{NH}_{2}$ & 0.6 & 0 & 14 & $<0.0001$ \\
\hline Dendrimer control & $\mathrm{G} 4 \mathrm{NH}_{2}$ & 1 & 0 & 16 & $<0.0001$ \\
\hline
\end{tabular}


Table 3. Effect of F1, F2 and F3 on control HEK 293 cells.

\begin{tabular}{|c|c|c|c|c|c|}
\hline Formulation & Dendrimer & [Dendrimer] $\mathrm{mg} / \mathrm{mL}$ & [Curcumin] mg/mL & Cell Viability (\%) & $p$ Value \\
\hline F1 & G4 90/10-Cys & 0.2 & 0.02 & 100 & 0.0151 \\
\hline F2 & G4 90/10-Cys & 0.6 & 0.06 & 85 & 0.12 \\
\hline F3 & G4 90/10-Cys & 1 & 0.1 & 10 & 0.02 \\
\hline Dendrimer control & G4 90/10-Cys & 0.2 & 0 & 100 & 0.68 \\
\hline Dendrimer control & G4 90/10-Cys & 0.6 & 0 & 100 & 0.46 \\
\hline Dendrimer control & G4 90/10-Cys & 1 & 0 & 100 & 0.54 \\
\hline Dendrimer control & $\mathrm{G} 4 \mathrm{NH}_{2}$ & 0.2 & 0 & 48 & $<0.0001$ \\
\hline Dendrimer control & $\mathrm{G} 4 \mathrm{NH}_{2}$ & 0.6 & 0 & 42 & $<0.0001$ \\
\hline Dendrimer control & $\mathrm{G} 4 \mathrm{NH}_{2}$ & 1 & 0 & 24 & $<0.0001$ \\
\hline
\end{tabular}

2.4.2. Effect of Curcumin Conjugated Dendrimers on Rat-Derived Cancer Cells (F98) and Rat Bone Marrow-Derived Mesenchymal Stem Cells (Rat-MSCs)

For Rat-MSCs: G4 90/10-Cys had no significant loss of cell viability at any dose, and significantly increased cell viability at the highest dose. For G4 90/10-Cys; D = 0.02 $\mathrm{mg} / \mathrm{mL}, p=0.68, \mathrm{D}=0.6 \mathrm{mg} / \mathrm{mL}, p=0.47, \mathrm{D}=1.0 \mathrm{mg} / \mathrm{mL} p=0.022$. For G4 90/10-Cys-Cur, there was no significant loss of cell viability at any dose, and it significantly increased survivability at its lowest and highest doses; $\mathrm{D}=0.02 \mathrm{mg} / \mathrm{mL} p=0.015, \mathrm{D}=0.06 \mathrm{mg} / \mathrm{mL}$, $p=0.124, \mathrm{D}=1.0 \mathrm{mg} / \mathrm{mL}, p=0.022$. For $\mathrm{G} 4 \mathrm{NH}_{2}, p<0.0001$ for all three doses.

The results shown in Figure 9 and Tables 4 and 5 demonstrate that curcumin encapsulated G4 90/10-Cys-Cur dendrimers (F1-F3) significantly reduced the viability of F98 cells compared to Curcumin alone. G4 90/10-Cys by itself showed negligible effects on either the cancer cells or healthy cells, while $\mathrm{G} 4 \mathrm{NH}_{2}$ caused significant reduction in the viability of both cancer and normal cells.

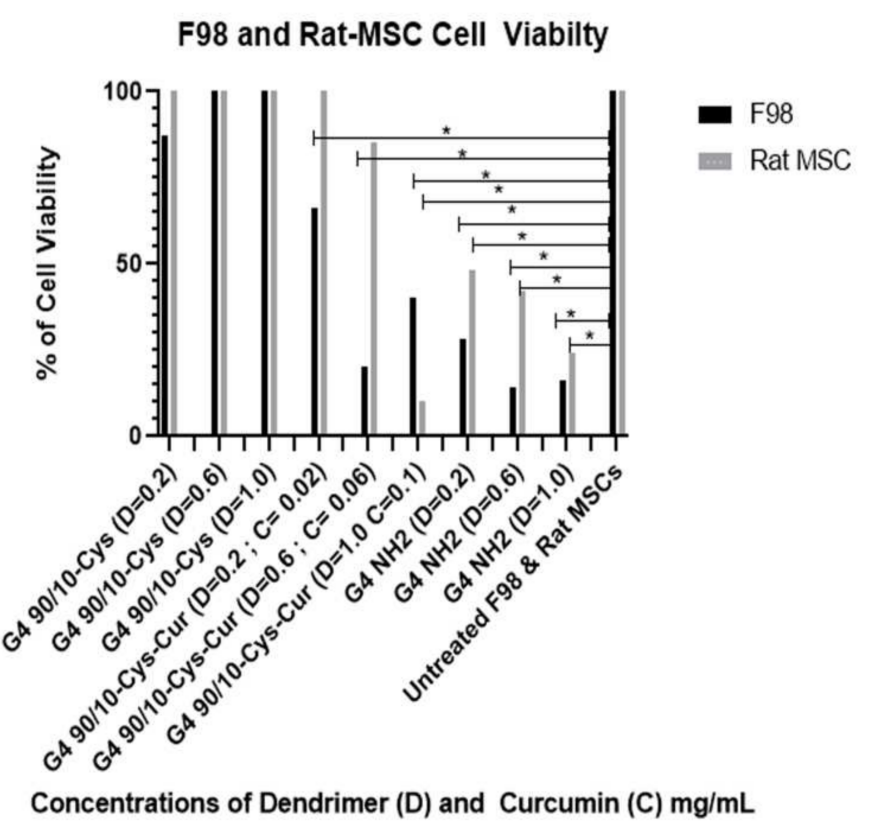

Figure 9. Viability of F98 and non-cancerous rat MSCs after 24 h treatment with G4 90/10-Cys, G4 90/10-Cys-Cur, and G4 NH2. For F98: G4 90/10-Cys there was no loss of cell viability and increased cell viability at the dose of $1.0 \mathrm{mg} / \mathrm{mL}$. For G4 90/10-Cys; D $=0.02 \mathrm{mg} / \mathrm{mL}, p=0.94, \mathrm{D}=0.47$, $p=0.017$. $\mathrm{D}=1.0 \mathrm{mg} / \mathrm{mL} p=0.0001$. For G4 90/10-Cys-Cur $p<0.0001$ for all three doses. For the cell treated with $\mathrm{NH}_{2}$, cell viability was significantly lost at every dose; $\mathrm{D}=0.02 \mathrm{mg} / \mathrm{mL}, p=0.0019$, $\mathrm{D}=0.06 \mathrm{mg} / \mathrm{mL}, p=0.0001, \mathrm{D}=1.0 \mathrm{mg} / \mathrm{mL}, p=0.0001$. ${ }^{*} p<0.05$. 
Table 4. Effect of F1, F2 and F3 and on F98 cells.

\begin{tabular}{cccccc}
\hline Formulation & Dendrimer & [Dendrimer] $\mathbf{m g} / \mathbf{m L}$ & [Curcumin] $\mathbf{m g} / \mathbf{m L}$ & Cell Viability (\%) & $p$ Value \\
\hline F1 & G4 90/10-Cys & 0.2 & 0.02 & 66 & 0.0015 \\
F2 & G4 90/10-Cys & 0.6 & 0.06 & 20 & $<0.0001$ \\
F3 & G4 90/10-Cys & 1 & 0.1 & 0.0001 \\
Dendrimer control & G4 90/10-Cys & 0.02 & 0 & 85 & 0.94 \\
Dendrimer control & G4 90/10-Cys & 0.06 & 0 & 100 & 0.47 \\
Dendrimer control & G4 90/10-Cys & 0.1 & 0 & 53 & 0.017 \\
Dendrimer control & G4 NH & 0.2 & 0 & 19 & 0.0019 \\
Dendrimer control & G4 NH & 0.6 & 0 & 21 & $<0.0001$ \\
Dendrimer control & $\mathrm{G}_{2} \mathrm{NH}_{2}$ & 1 & & $<0.0001$ \\
\hline
\end{tabular}

Table 5. Effect of F1, F2 and F3on Rat MSC control cells.

\begin{tabular}{|c|c|c|c|c|c|}
\hline Formulation & Dendrimer & [Dendrimer] $\mathrm{mg} / \mathrm{mL}$ & [Curcumin] mg/mL & Cell Viability (\%) & $p$ Value \\
\hline $\mathrm{F} 1$ & G4 90/10-Cys & 0.2 & 0.02 & 100 & 0.015 \\
\hline $\mathrm{F} 2$ & G4 90/10-Cys & 0.6 & 0.06 & 100 & 0.124 \\
\hline F3 & G4 90/10-Cys & 1 & 0.1 & 100 & 0.022 \\
\hline Dendrimer control & G4 90/10-Cys & 0.02 & 0 & 100 & 0.68 \\
\hline Dendrimer control & G4 90/10-Cys & 0.06 & 0 & 100 & 0.47 \\
\hline Dendrimer control & G4 90/10-Cys & 0.1 & 0 & 100 & 0.18 \\
\hline Dendrimer control & $\mathrm{G} 4 \mathrm{NH}_{2}$ & 0.2 & 0 & 38 & $<0.0001$ \\
\hline Dendrimer control & $\mathrm{G} 4 \mathrm{NH}_{2}$ & 0.6 & 0 & 0 & $<0.0001$ \\
\hline Dendrimer control & $\mathrm{G} 4 \mathrm{NH}_{2}$ & 1 & 0 & 2 & $<0.0001$ \\
\hline
\end{tabular}

2.4.3. Effect of Curcumin Conjugated Dendrimers on Mouse-Derived Cancer Cells (GL261) and Mouse Bone Marrow-Derived Mesenchymal Stem Cells (Mouse-MSCs)

For Mouse MSCs: cell viability was not lost at any dose, and was significantly increased at the higher two doses: G4 90/10-Cys; $\mathrm{D}=0.02 \mathrm{mg} / \mathrm{mL}, p=0.974, \mathrm{D}=0.06 \mathrm{mg} / \mathrm{mL}$, $p=0.0009, \mathrm{D}=1.0 \mathrm{mg} / \mathrm{mL} p=0.0001$. For G4 90/10-Cys-Cur $p<0.0001$ for all three doses. For the control $\mathrm{NH}_{2}$, cell viability was significantly lost at every dose; $\mathrm{D}=0.02 \mathrm{mg} / \mathrm{mL}$, $p=0.0038, \mathrm{D}=0.06 \mathrm{mg} / \mathrm{mL}, p=0.0001, \mathrm{D}=1.0 \mathrm{mg} / \mathrm{mL}, p=0.0001$.

Figure 10 and Tables 6 and 7 demonstrate that curcumin encapsulated G4 90/10Cys dendrimers (F1-F3) significantly reduced the viability of GL261 cells compared to Curcumin alone. Curcumin by itself, $(0.1 \mathrm{mg} / \mathrm{mL})$ did not kill the GL261 cells or control MSCs (100\% cell viability; data not shown). G4 90/10-Cys by itself showed negligible effects on either the cancer cells or healthy cells, while $\mathrm{G} 4 \mathrm{NH}_{2}$ significantly reduced the viability of both cancer and normal cells.

Table 6. Effect of F1, F2 and F3 on GL261 glioblastoma cells.

\begin{tabular}{|c|c|c|c|c|c|}
\hline Formulation & Dendrimer & [Dendrimer] $\mathrm{mg} / \mathrm{mL}$ & [Curcumin] mg/mL & Cell Viability (\%) & $p$ Value \\
\hline F1 & G4 90/10-Cys & 0.2 & 0.02 & 68 & $<0.0001$ \\
\hline F2 & G4 90/10-Cys & 0.6 & 0.06 & 17 & $<0.0001$ \\
\hline F3 & G4 90/10-Cys & 1 & 0.1 & 22 & $<0.0001$ \\
\hline Dendrimer control & G4 90/10-Cys & 0.02 & 0 & 94 & 0.974 \\
\hline Dendrimer control & G4 90/10-Cys & 0.06 & 0 & 100 & 0.0009 \\
\hline Dendrimer control & G4 90/10-Cys & 0.1 & 0 & 100 & $<0.0001$ \\
\hline Dendrimer control & $\mathrm{G} 4 \mathrm{NH}_{2}$ & 0.2 & 0 & 68 & 0.0038 \\
\hline Dendrimer control & $\mathrm{G} 4 \mathrm{NH}_{2}$ & 0.6 & 0 & 14 & $<0.0001$ \\
\hline Dendrimer control & $\mathrm{G} 4 \mathrm{NH}_{2}$ & 1 & 0 & 13 & $<0.0001$ \\
\hline
\end{tabular}


GL261 and Mouse-MSC Cell Viability

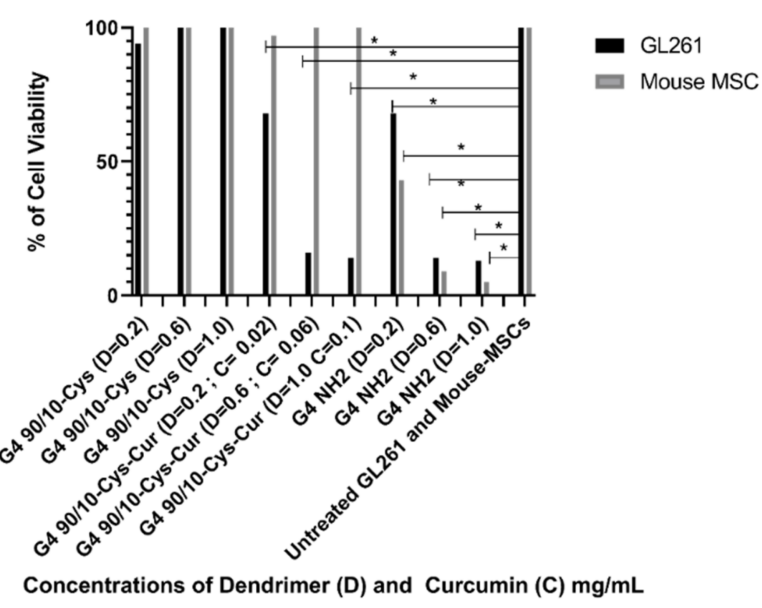

Figure 10. Viability of GL261 and non-cancerous mouse MSCs after $24 \mathrm{~h}$ treatment with G4 90/10Cys, G4 90/10-Cys-Cur, and G4 NH2. For GL261, cell viability was not lost at any dose, and was significantly increased at the higher two doses: G4 90/10-Cys; $\mathrm{D}=0.02 \mathrm{mg} / \mathrm{mL}, p=0.974$, $\mathrm{D}=0.06 \mathrm{mg} / \mathrm{mL}, p=0.0009, \mathrm{D}=1.0 \mathrm{mg} / \mathrm{mL} p=0.0001$. For G4 90/10-Cys-Cur $p<0.0001$ for all three doses. For the cell treated with $\mathrm{NH}_{2}$, cell viability was significantly lost at every dose; $\mathrm{D}=0.02 \mathrm{mg} / \mathrm{mL}, p=0.0038, \mathrm{D}=0.06 \mathrm{mg} / \mathrm{mL}, p=0.0001, \mathrm{D}=1.0 \mathrm{mg} / \mathrm{mL}, p=0.0001 .{ }^{*} p<0.05$.

Table 7. Effect of F1, F2 and F3 on Mouse MSC control cells.

\begin{tabular}{|c|c|c|c|c|c|}
\hline Formulation & Dendrimer & [Dendrimer] $\mathrm{mg} / \mathrm{mL}$ & [Curcumin] mg/mL & Cell Viability (\%) & $p$ Value \\
\hline $\mathrm{F} 1$ & G4 90/10-Cys & 0.2 & 0.02 & 97 & $>0.999$ \\
\hline F2 & G4 90/10-Cys & 0.6 & 0.06 & 100 & 0.38 \\
\hline F3 & G4 90/10-Cys & 1 & 0.1 & 100 & 0.93 \\
\hline Dendrimer control & G4 90/10-Cys & 0.02 & 0 & 100 & $>0.999$ \\
\hline Dendrimer control & G4 90/10-Cys & 0.06 & 0 & 100 & 0.98 \\
\hline Dendrimer control & G4 90/10-Cys & 0.1 & 0 & 100 & $>0.99$ \\
\hline Dendrimer control & $\mathrm{G} 4 \mathrm{NH}_{2}$ & 0.2 & 0 & 43 & 0.026 \\
\hline Dendrimer control & $\mathrm{G} 4 \mathrm{NH}_{2}$ & 0.6 & 0 & 0 & $<0.0001$ \\
\hline Dendrimer control & $\mathrm{G} 4 \mathrm{NH}_{2}$ & 1 & 0 & 0 & 0.0002 \\
\hline
\end{tabular}

\section{Discussion}

Dendrimer nano-molecules are increasingly used in nanotherapeutic research, particularly for the treatment of cancers, due to their small size and ability to encapsulate and deliver non-soluble treatments deep into the tumor. Over the past few years, our lab has focused on the delivery of the polyphenol curcumin, and has found that, by encapsulating this nutraceutical inside fourth generation PAMAM dendrimers, we were able to encapsulate the curcumin, thereby increasing curcumin bioavailability.

Under our experimental conditions, curcumin by itself was ineffective at killing any of the cancer cell lines (human, rat or mouse). This may be related to its extremely poor solubility in water, thereby decreasing its bioavailability. Encapsulating curcumin into the mixed surface dendrimer (G4 90/10-Cys) showed a remarkable increase in its anti-cancer properties. In the case of the human cancer cell line (U87), even the lowest dose tested $(0.02 \mathrm{mg} / \mathrm{mL})$ killed $100 \%$ of the cancer cells while showing no effect on the healthy HEK 293 control cells ( $0 \%$ killing). A similar trend was noted with the mid-dose of $0.06 \mathrm{mg} / \mathrm{mL}$ encapsulated curcumin. However, at the highest dose $(0.1 \mathrm{mg} / \mathrm{mL}), 90 \%$ of healthy HEK 293 cells were also killed. These results suggest that there is an optimum dose range of encapsulated curcumin that would be effective for glioblastoma treatment (Figure 8).

Encapsulated curcumin was less effective in killing mouse (GL 261) or rat (F98) cancer cells. In the case of mouse cells, the lowest dose $(0.02 \mathrm{mg} / \mathrm{mL})$ showed about $30 \% \mathrm{killing}$ while the highest dose $(0.1 \mathrm{mg} / \mathrm{mL})$ gave about $80 \%$ killing of the cancer cells. None of 
the doses tested showed any deleterious effects on the control rat or mouse (healthy) cells (Figures 9 and 10).

Concordant with previous research, $\mathrm{G}_{4} \mathrm{NH}_{2}$ was found to be extremely toxic, reducing cell viability in all 6 cell types, even at low doses. However, these experiments did support our hypothesis that by reducing the number of surface amines, we reduced dendrimer toxicity to both healthy and cancerous cells. The mixed surface G4 90/10-Cys showed no significant reduction in cell viability in all 3 of the cancer lines, or any of the control lines. We conclude that mixed surface dendrimers are safe and effective candidates for vehicle delivery systems, due to their small $(\sim 4 \mathrm{~nm})$ size and ability to encapsulate cargo (curcumin). Additionally, by encapsulating curcumin inside our G4 90/10-Cys we were able to increase the effectiveness of the cargo compared to free curcumin.

When compared to our G4 $\mathrm{NH}_{2}$ toxicity control, we found that our G4 90/10-Cys-Cur was actually more efficient at killing U87 cells than the $\mathrm{G} 4 \mathrm{NH}_{2}$, at all three doses. While this was not reproduced in the rodent cell lines, it shows that the human glioblastoma cell line, in particular, may be more sensitive to treatment with G4 90/10-Cys-Cur. These results will be used to help guide treatment options and concentration doses for a glioblastoma tumor model in vivo.

Potential new pharmacotherapeutics emerge from biological sources, chemical molecules, vaccines, and other untapped or re-purposed biological sources. Medicines developed from different sources can respond to genetic predisposition, risk factors, and comorbid conditions, producing potential adverse effects in humans, which makes selection of suitable candidates for clinical trials difficult. This difficulty is mitigated with the help of multi-species drug testing studies [26]. Based on the complexity of using "designer therapies", it has become a necessary requisite of global regulatory bodies to test new therapeutics in animals prior to human trials (U.S. FDA document: https: / / www.fda.gov/media/72028/download) (accessed on 25 May 2021). The multispecies preclinical studies provide us with safety and tolerability data of new drugs to support the initial therapeutic dose and long-term drug dosing calculations for clinical trials. Taken together, our treatments with encapsulated curcumin have reduced cellular viability across 3 species while leaving control cells relatively healthy at all but one of those same doses. Additionally, our G4 90/10-Cys and G4 90/10-Cys-Cur have proven to be safe when tested on control tissue at lower doses and, therefore, could be used as an adjunctive treatment or potential vehicle in the treatment of GB.

Temozolomide is the current gold standard of treatment for GB. However, in nearly $50 \%$ of patients this drug is ineffective, largely due to a natural drug resistance resulting from overexpression of the MGMT gene. Recent data suggest that curcumin, in addition to its many anticancer effects, may function to prevent drug resistance in certain types of cancer [23]. Other labs have already shown promising results when combining curcumin containing treatments with Temozolomide $[27,28]$. Treatments with just curcumin have largely failed in clinical trials due to its poor solubility, quick degradation, and elimination from the body before it can deliver its full therapeutic effect. By encapsulating curcumin inside a dendrimer nano-molecule, we increased its therapeutic efficacy by improving bioavailability, its release kinetics over a period of time, reducing the rate at which it is released and broken down and eliminated from the body.

Our findings are limited due to the lack of defined mechanisms underlying the MTT data. Curcumin works on multiple cell cycle pathways and tumor suppressor proteins [29]. It appears that the curcumin is responsible for the reduction in cellular viability of cancer cells, and not the increase in amines on the surface. More investigations are needed to determine if the importance of the curcumin concentration encapsulated in our dendrimers plays a role in the cell viability. However, delineating which specific genes are responsible for these effects is important in tailoring the therapy to individuals or for combined adjunctive treatment. Future in vitro studies in this lab will include testing hybrid treatments with G4 90/10-Cys-Cur in addition to a chemotherapeutic, such as Temozolomide, to assess their effects on cancerous and healthy tissue cell lines. Based on the results of the in vitro 
work, future in vivo studies will include delivering these treatments into rodent models of glioblastoma to assess their potential where other treatments have failed.

\section{Materials and Methods}

\subsection{Synthesis of G4 90/10-Cys and Curcumin Encapsulation}

G4 90/10-Cys: Surface-modified G4 90/10-Cys dendrimers were synthesized as previously described [25]. Encapsulation was performed by adding G4 90/10 and curcumin at 10:1 $(w / w)$ ratio in ethanol. After mixing, the ethanol was evaporated in a vacuum oven. The resulting residue was stored in the refrigerator. On the day of the experiment, the residue was reconstituted with Hank's balanced salt solution (HBSS). The reconstituted formulation was used within a day. The $\mathrm{pH}$ of the formulations was around 7.

\subsection{Acidic PAGE and RP-HPLC}

This was carried out as previously described [30]. Briefly, a 10\% acidic PAGE gel was used. Samples were mixed with $50 \%$ sucrose and added to the wells. Coomassie blue was used to stain the gel. For HPLC, a C18 column was used with Hitachi HPLC system (Hitachi, Tokyo, Japan). Mobile phase A was water (with $0.1 \%$ trifluoroacetic acid) and mobile phase $B$ was $0.085 \%$ trifluoroacetic acid in acetonitrile.

\subsection{Animals}

Donor for the mouse cells were 1 male and 2 female C57BL/6J mice, bred in-house aged between 10 and 15 weeks old. All mice were group-housed in a clear polycarbonate container with sawdust bedding and access to food and water ad libitum. The room temperature was set to $22{ }^{\circ} \mathrm{C}$ and on the room is under control of an automatic timer creating a $12 \mathrm{~h}$ light/dark cycle (lights $\mathrm{ON}$ at 12:00 a.m.). The experimental procedures are approved by IACUC of CMU (CMU IACUC protocol \#18-23).

Donors for the rat cells were 1 male and 2 female Sprague Dawley rats, bred in-house aged between 10-15 weeks old. All rats were group-housed in a clear polycarbonate container with sawdust bedding and access to food and water ad libitum. The room temperature was set to $22{ }^{\circ} \mathrm{C}$ and on the room is under control of an automatic timer creating a $12 \mathrm{~h}$ light/dark cycle (lights $\mathrm{ON}$ at 12:00 a.m.). The experimental procedures are approved by IACUC of CMU (CMU IACUC protocol \#18-12).

\subsection{Maintenance of Different Cell Lines \\ 4.4.1. U87}

Human glioblastoma U87 cells: These cells were purchased from ATCC (American Type Tissue Collection, Manassas, VA, USA). Cells were cultured in Dulbecco's Modified Eagle Medium (DMEM; Gibco, Waltham, MA, USA), with 10\% Fetal Bovine Serum (FBS; Fisher Scientific, Waltham, MA, USA), and 1\% penicillin/Streptomycin (Gibco, Waltham, MA, USA) in T-75 flasks and incubated at $37{ }^{\circ} \mathrm{C}$ with $5 \% \mathrm{CO}_{2}$. Cells were cultured until $80 \%$ confluent. The media was removed, and the cells were washed with PBS, and $3 \mathrm{~mL}$ of $0.25 \%$ trypsin (Gibco, Waltham, MA, USA) was added to the flask and dispersed evenly until cells began to dissociate at $37^{\circ} \mathrm{C}$ for $3-5 \mathrm{~min}$. The trypsin was removed and the cells were placed in a $15 \mathrm{~mL}$ conical tube with $3 \mathrm{~mL}$ of fresh media, which was centrifuged at $1200 \mathrm{rpm}$ for $7 \mathrm{~min}$. The supernatant was removed, leaving a pellet of cells at the bottom of the tube. One $\mathrm{mL}$ of fresh media was added and mixed gently. An aliquot of $10 \mu \mathrm{L}$ of this cell/media mixture was then used to count cells using a hemocytometer, after which the cells were re-plated in a 96 well plate at a density of 10,000 cells per well. A stock of cells was cultured until passage 7 and then stored in a $-80{ }^{\circ} \mathrm{C}$ ultra-freezer until further use. All cells used in this study were passaged the same way and used at passage 8 to eliminate variability. 


\subsubsection{HEK 293}

Human Embryonic Kidney 293 cells: Cells were purchased from American Type Culture Collection (ATCC, Manassas, VA, USA). Cells were cultured as previously described in DMEM (Gibco, Waltham, MA, USA), with 10\% FBS (Fisher Scientific, Waltham MA, USA), and 1\% penicillin/streptomycin (PS; Gibco, Waltham, MA, USA) in T75 $\mathrm{cm}^{2}$ (T-75) tissue culture flasks and incubated at $37{ }^{\circ} \mathrm{C}$ at $5 \% \mathrm{CO}_{2}$, until $75 \%$ confluent. They were then passaged and re-plated in a 96 well plate at 10,000 cells per well for use.

\subsubsection{F98}

Rat cancer cells were purchased from ATCC (American Type Tissue Collection, Manassas, VA, USA). Cells were cultured in DMEM (Gibco, Waltham, MA, USA) with 10\% FBS (Fisher Scientific, Waltham, MA, USA) and $1 \%$ PS in T-75 and incubated at $37^{\circ} \mathrm{C}$ with $5 \% \mathrm{CO}_{2}$ until $75 \%$ confluent. Cells were then passaged and replated in a 96 well plate at 10,000 cells per well until use.

\subsubsection{Rat MSCs}

Rat bone marrow-derived MSCs were isolated and cultured, as previously described [30]. In brief, 3 adult Sprague Dawley rats were euthanized under anesthesia, and the femur and tibia of both sides were removed. After washing with sterile PBS, the bones were flushed out with $\alpha$-MEM (Gibco, Waltham, MA, USA) to get bone marrow cells. Cells were then plated in a T-25 in $\alpha$-MEM with $10 \%$ FBS (Gibco, Waltham, MA, USA), $10 \%$ horse serum (HS; Gibco, Waltham, MA, USA), and 1\% PS (Gibco, Waltham, MA, USA).

\subsubsection{GL261 Red-FLuc}

Mouse glioma cells were purchased from Bioware Brite (BW134246V), Perkin Elmer (Waltham, MA, USA) pre-engineered with a firefly luciferase gene from Luciola Italica (RedFLuc, Waltham, MA, USA). Cells were cultured in Dulbecco's Modified Eagle Medium (DMEM; Gibco, Waltham, MA, USA), with 10\% Fetal Bovine Serum (FBS; Fisher Scientific, Waltham, MA, USA), and 1\% PS (Gibco, Waltham, MA, USA) in T-75 flasks and incubated at $37^{\circ} \mathrm{C}$ with $5 \% \mathrm{CO}_{2}$. Cells were cultured until $75 \%$ confluent. Cells were then passaged and replated in a 96 well plate at 10,000 cells per well until use.

\subsubsection{Mouse MSCs}

Mouse bone marrow-derived MSCs were isolated and cultured, as previously described [31]. In brief, 3 adult C57BL/6J mice were euthanized and the femur and tibias from each side were taken. After washing in sterile PBS, the bones were flushed with DMEM (Gibco, Waltham, MA, USA). Cells were then plated in a T-25 in DMEM with 10\% FBS (Gibco, Waltham, MA, USA), 10\% HS (Gibco, Waltham, MA, USA), and 1\% PS (Gibco, Waltham, MA, USA).

\subsection{MTT Assay}

U87 and their control HEK 293; F98 and their control Rat MSC; GL261, and their control mouse MSCs were each plated in 96 well plates for MTT assay using the protocol previously established by ATCC (American Type Culture Collection, Manassas, VA, USA; Figure 11). Unencapsulated curcumin, G4 $\mathrm{NH}_{2}, \mathrm{G} 4$ 90/10-Cys, and G4 90/10-Cys-Cur dendrimers were tested in concentrations of $0.2,0.6,1.0 \mathrm{mg} / \mathrm{mL}$ on all cell lines. In brief, 10,000 cells were plated in each well in $100 \mu \mathrm{L}$ of media. Once the cells were $70 \%$ confluent, the treatments were added in triplicates at each concentration, leaving 3 wells for untreated cells and 3 wells with just media as an internal control. Twenty-four hours following treatment, the media was removed and $100 \mu \mathrm{L}$ of fresh media was added to each well. The MTT reagent was dissolved in deionized water at a concentration of $5 \mathrm{mg} / \mathrm{mL}$, and $10 \mu \mathrm{L}$ was added to each well and then placed back in the incubator for four hours at $37^{\circ} \mathrm{C}$ with $5 \% \mathrm{CO}_{2}$. The plates were then removed from the incubator and $100 \mu \mathrm{L}$ of detergent reagent consisting of $0.01 \mathrm{M}$ hydrochloric acid in $10 \%$ sodium dodecyl sulfate was added 
to each well. The plates were then covered and left at room temperature for two hours in the dark and were then read on a spectrophotometer at an absorbance of $570 \mathrm{~nm}$. Optimal doses can be assessed by determining which causes maximal cell death in the glioblastoma cells without affecting the control cells. During the MTT assay, all treatments and controls were performed in triplicate. Percent cell viability was determined by first averaging the absorbance rates of the three untreated wells of cells. Their average absorbance was then used as a control set at $100 \%$ cell viability. The absorbance rate triplicates for each sample were averaged and divided by the control to obtain the percentage of cell viability for each treatment.

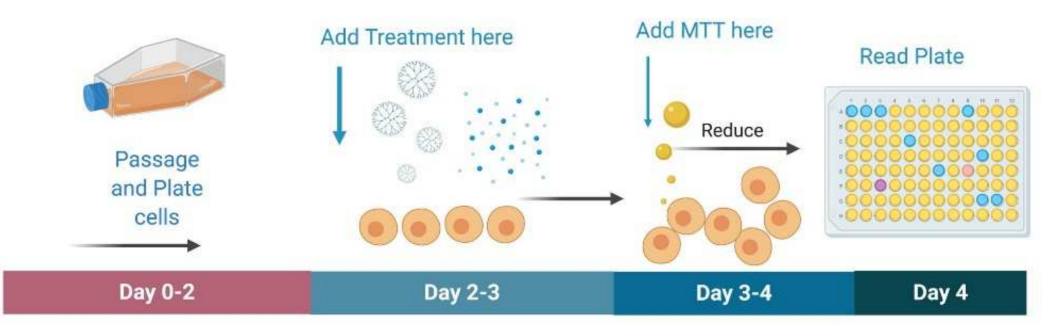

Figure 11. Schematic of MTT assay. For the MTT assay, cells are passaged and plated in a 96 well plate. Once confluent, treatment is added in triplicates to incubate for $24 \mathrm{~h}$. Afterwards, MTT dye is added and incubated for four hours. MTT detergent reagent is then added and incubated for $2 \mathrm{~h}$ in the dark. Plates are then read on a spectrophotometer at $570 \mathrm{~nm}$.

\subsection{Statistical Analysis}

All statistical analysis was done using GraphPad Prism 8 (GraphPad, San Diego, CA, USA). One-way ANOVA with Tukey's Post Hoc comparison was done to assess significant reductions in cell viability using an MTT assay. An alpha level of $p<0.05$ was used for all analyses.

\section{Conclusions}

A formidable barrier to treating GB is delivering therapeutics to the tumor in a safe and efficient way. The novel PAMAM dendrimer described in this study represents a first step as a promising method of overcoming this major obstacle. Our study demonstrated that delivering curcumin (which otherwise has limited bioavailability) to cancer cells in vitro is lethal to different glioblastoma cell lines from three different species. Our new method of encapsulation of curcumin seems to be only toxic to cancer cells and therefore could be a new alternative to treat the devastating glioblastoma.

Author Contributions: Conceptualization, J.G., B.S. and J.R.; Data curation, J.G., G.H., J.M., A.R., D.S. and A.S.; Formal analysis, J.G., G.H., A.S., G.D. and J.R.; Funding acquisition, A.S., G.D. and J.R.; Investigation, J.G., A.S. and J.R.; Methodology, J.G., B.S., A.S. and J.R.; Project administration, J.G., B.S., A.S., G.D. and J.R.; Resources, A.S., G.D. and J.R.; Supervision, J.G., B.S., D.S.K., D.S., A.S., G.D. and J.R.; Validation, B.S., A.S., G.D. and J.R.; Visualization, J.G., B.S., G.D. and J.R.; Writing-original draft, J.G., K.G., S.K., P.S.O., C.A.B., A.S. and J.R.; Writing-review and editing, J.G., B.S., K.G., D.S.K., A.S., G.D. and J.R. All authors have read and agreed to the published version of the manuscript.

Funding: This research received no external funding.

Institutional Review Board Statement: This study was carried out in accordance with the protocols approved by the Institutional Animal Care and Use Committee of the Central Michigan University (IACUC 18-23 August 2018, and 18-12 June 2018).

Informed Consent Statement: Not applicable.

Data Availability Statement: Not applicable. 
Acknowledgments: We would like to thank Robert B. Petersen for his helpful comments, the Program in Neuroscience, the College of Medicine, the Chemistry and Biochemistry Department, the John G. Kulhavi Professorship in Neuroscience at Central Michigan University, and the Field Neurosciences Institute.

Conflicts of Interest: The authors declare no conflict of interest.

Sample Availability: Samples of the dendrimers and the dendrimer encapsulated curcumin are available from the corresponding author.

$\begin{array}{ll}\text { Abbreviations } & \\ \text { ATCC } & \text { American Type Tissue Collection } \\ \text { G4 } 90 / 10 & \text { Generation 4, 90\% hydroxyl, 10\% amines } \\ \text { G4 90/10-Cys } & \text { Generation 4,90\% hydroxyl, 10\% amines, cystamine core } \\ \text { G4 90/10-Cys-Cur } & \text { Generation 4, 90\% hydroxyl, 10\% amines, cystamine core with curcumin } \\ \text { BBB } & \text { Blood Brain Barrier } \\ \text { BBTB } & \text { Blood Brain Tumor Barrier } \\ \text { Cur } & \text { Curcumin } \\ \text { Cys } & \text { Cystamine } \\ \text { DMEM } & \text { Dulbecco's Modified Eagle Medium } \\ \text { FBS } & \text { Fetal Bovine Serum } \\ \text { GB } & \text { Glioblastoma } \\ \text { GSH } & \text { Glutathione } \\ \text { MGMT } & \text { O }{ }^{6} \text {-methylguanine methyltransferase } \\ \text { MTT } & \text { 3-(4,5-dimethylthiazol-2-yl)-2,5-diphenyltetrazolium bromide } \\ \text { NH }{ }_{2}, \text { NH }_{3}{ }^{+} & \text {Amines } \\ \text { OH } & \text { Hydroxyl } \\ \text { PAGE } & \text { Polyacrylamide gel electrophoresis } \\ \text { PAMAM } & \text { Polyamidoamine } \\ \text { PBS } & \text { Phosphate Buffer Saline } \\ \text { RP-HPLC } & \text { Reverse Phase High-Performance Liquid Chromatography } \\ \text { TMZ } & \text { Temozolomide } \\ \text { MSC } & \text { Mesenchymal stem cells } \\ \text { HEK } & \text { Human embryonic Kidney } \\ \text { HS } & \text { Horse serum } \\ \text { PS } & \text { Penicillin Steptomycin }\end{array}$

\section{References}

1. Shahar, T.; Nossek, E.; Steinberg, D.M.; Rozovski, U.; Blumenthal, D.T.; Bokstein, F.; Sitt, R.; Freedman, S.; Corn, B.W.; Kanner, A.A.; et al. The Impact of Enrollment in Clinical Trials on Survival of Patients with Glioblastoma. J. Clin. Neurosci. 2012, 19, 1530-1534. [CrossRef] [PubMed]

2. Delgado-López, P.D.; Corrales-García, E.M. Survival in Glioblastoma: A Review on the Impact of Treatment Modalities. Clin. Transl. Oncol. 2016, 18, 1062-1071. [CrossRef] [PubMed]

3. Oliva, C.R.; Nozell, S.E.; Diers, A.; McClugage, S.G.; Sarkaria, J.N.; Markert, J.M.; Darley-Usmar, V.M.; Bailey, S.M.; Gillespie, G.Y.; Landar, A.; et al. Acquisition of Temozolomide Chemoresistance in Gliomas Leads to Remodeling of Mitochondrial Electron Transport Chain. J. Biol. Chem. 2010, 285, 39759-39767. [CrossRef] [PubMed]

4. Thomas, A.; Tanaka, M.; Trepel, J.; Reinhold, W.C.; Rajapakse, V.N.; Pommier, Y. Temozolomide in the Era of Precision Medicine. Cancer Res. 2017, 77, 823-826. [CrossRef]

5. Lee, S.Y. Temozolomide Resistance in Glioblastoma Multiforme. Genes Dis. 2016, 3, 198-210. [CrossRef]

6. Lestari, M.L.A.D.; Indrayanto, G. Curcumin. Profiles Drug Subst. Excip. Relat. Methodol. 2014, 39, 113-204. [CrossRef]

7. Mishra, S.; Palanivelu, K. The Effect of Curcumin (Turmeric) on Alzheimer's Disease: An Overview. Ann. Indian Acad. Neurol. 2008, 11, 13-19. [CrossRef]

8. Meng, B.; Li, J.; Cao, H. Antioxidant and Antiinflammatory Activities of Curcumin on Diabetes Mellitus and Its Complications. Curr. Pharm. Des. 2013, 19, 2101-2113.

9. Dhillon, N.; Aggarwal, B.B.; Newman, R.A.; Wolff, R.A.; Kunnumakkara, A.B.; Abbruzzese, J.L.; Ng, C.S.; Badmaev, V.; Kurzrock, R. Phase II Trial of Curcumin in Patients with Advanced Pancreatic Cancer. Clin. Cancer Res. 2008, 14, 4491-4499. [CrossRef] 
10. Masuelli, L.; Benvenuto, M.; Fantini, M.; Marzocchella, L.; Sacchetti, P.; Di Stefano, E.; Tresoldi, I.; Izzi, V.; Bernardini, R.; Palumbo, C.; et al. Curcumin Induces Apoptosis in Breast Cancer Cell Lines and Delays the Growth of Mammary Tumors in Neu Transgenic Mice. J. Biol. Regul. Homeost. Agents 2013, 27, 105-119.

11. Maiti, P.; Plemmons, A.; Dunbar, G.L. Combination Treatment of Berberine and Solid Lipid Curcumin Particles Increased Cell Death and Inhibited PI3K/Akt/MTOR Pathway of Human Cultured Glioblastoma Cells More Effectively than Did Individual Treatments. PLoS ONE 2019, 14, e0225660. [CrossRef]

12. Mansouri, K.; Rasoulpoor, S.; Daneshkhah, A.; Abolfathi, S.; Salari, N.; Mohammadi, M.; Rasoulpoor, S.; Shabani, S. Clinical Effects of Curcumin in Enhancing Cancer Therapy: A Systematic Review. BMC Cancer 2020, 20, 791. [CrossRef]

13. Sharma, R.A.; McLelland, H.R.; Hill, K.A.; Ireson, C.R.; Euden, S.A.; Manson, M.M.; Pirmohamed, M.; Marnett, L.J.; Gescher, A.J.; Steward, W.P. Pharmacodynamic and Pharmacokinetic Study of Oral Curcuma Extract in Patients with Colorectal Cancer. Clin. Cancer Res. 2001, 7, 1894-1900.

14. Anand, P.; Kunnumakkara, A.B.; Newman, R.A.; Aggarwal, B.B. Bioavailability of Curcumin: Problems and Promises. Mol. Pharm. 2007, 4, 807-818. [CrossRef] [PubMed]

15. Wei, X.-Q.; Zhu, J.-F.; Wang, X.-B.; Ba, K. Improving the Stability of Liposomal Curcumin by Adjusting the Inner Aqueous Chamber PH of Liposomes. ACS Omega 2020, 5, 1120-1126. [CrossRef] [PubMed]

16. Van Tellingen, O.; Yetkin-Arik, B.; de Gooijer, M.C.; Wesseling, P.; Wurdinger, T.; de Vries, H.E. Overcoming the Blood-Brain Tumor Barrier for Effective Glioblastoma Treatment. Drug Resist. Updates 2015, 19, 1-12. [CrossRef]

17. Prasad, R.; Bhattacharyya, A.; Nguyen, Q.D. Nanotechnology in Sustainable Agriculture: Recent Developments, Challenges, and Perspectives. Front. Microbiol. 2017, 8, 1014. [CrossRef]

18. Tomalia, D.A.; Baker, H.; Dewald, J.; Hall, M.; Kallos, G.; Martin, S.; Roeck, J.; Ryder, J.; Smith, P. A New Class of Polymers: Starburst-Dendritic Macromolecules. Polym. J. 1985, 17, 117-132. [CrossRef]

19. Scott, R.W.J.; Wilson, O.M.; Crooks, R.M. Synthesis, Characterization, and Applications of Dendrimer-Encapsulated Nanoparticles. J. Phys. Chem. B 2005, 109, 692-704. [CrossRef]

20. Fana, M.; Gallien, J.; Srinageshwar, B.; Dunbar, G.L.; Rossignol, J. PAMAM Dendrimer Nanomolecules Utilized as Drug Delivery Systems for Potential Treatment of Glioblastoma: A Systematic Review. Int. J. Nanomed. 2020, 15, 2789-2808. [CrossRef]

21. Heiden, T.C.K.; Dengler, E.; Kao, W.J.; Heideman, W.; Peterson, R.E. Developmental Toxicity of Low Generation PAMAM Dendrimers in Zebrafish. Toxicol. Appl. Pharmacol. 2007, 225, 70-79. [CrossRef] [PubMed]

22. Chakravarthi, S.; Bulleid, N.J. Glutathione is Required to Regulate the Formation of Native Disulfide Bonds within Proteins Entering the Secretory Pathway. J. Biol. Chem. 2004, 279, 39872-39879. [CrossRef] [PubMed]

23. Xu, D.; Tian, W.; Shen, H. Curcumin Prevents Induced Drug Resistance: A Novel Function? Chin. J. Cancer Res. 2011, 23, 218-223. [CrossRef]

24. Zbinden, G. The Concept of Multispecies Testing in Industrial Toxicology. Regul. Toxicol. Pharmacol. 1993, 17, 85-94. [CrossRef]

25. Srinageshwar, B.; Peruzzaro, S.; Andrews, M.; Johnson, K.; Hietpas, A.; Clark, B.; McGuire, C.; Petersen, E.; Kippe, J.; Stewart, A.; et al. PAMAM Dendrimers Cross the Blood-Brain Barrier When Administered through the Carotid Artery in C57BL/6J Mice. Int. J. Mol. Sci. 2017, 18, 628. [CrossRef] [PubMed]

26. Steinmetz, K.L.; Spack, E.G. The Basics of Preclinical Drug Development for Neurodegenerative Disease Indications. BMC Neurol. 2009, 9 (Suppl. 1), S2. [CrossRef]

27. Dilnawaz, F.; Sahoo, S.K. Enhanced Accumulation of Curcumin and Temozolomide Loaded Magnetic Nanoparticles Executes Profound Cytotoxic Effect in Glioblastoma Spheroid Model. Eur. J. Pharm. Biopharm. 2013, 85, 452-462. [CrossRef] [PubMed]

28. Bagherian, A.; Mardani, R.; Roudi, B.; Taghizadeh, M.; Banfshe, H.R.; Ghaderi, A.; Davoodvandi, A.; Shamollaghamsari, S.; Hamblin, M.R.; Mirzaei, H. Combination Therapy with Nanomicellar-Curcumin and Temozolomide for In vitro Therapy of Glioblastoma Multiforme via Wnt Signaling Pathways. J. Mol. Neurosci. 2020, 70, 1471-1483. [CrossRef] [PubMed]

29. Sa, G.; Das, T. Anti Cancer Effects of Curcumin: Cycle of Life and Death. Cell Div. 2008, 3, 14. [CrossRef] [PubMed]

30. Rossignol, J.; Boyer, C.; Lévèque, X.; Fink, K.D.; Thinard, R.; Blanchard, F.; Dunbar, G.L.; Lescaudron, L. Mesenchymal Stem Cell Transplantation and DMEM Administration in a 3NP Rat Model of Huntington's Disease: Morphological and Behavioral Outcomes. Behav. Brain Res. 2011, 217, 369-378. [CrossRef]

31. Rossignol, J.; Fink, K.D.; Crane, A.T.; Davis, K.K.; Bombard, M.C.; Clerc, S.; Bavar, A.M.; Lowrance, S.A.; Song, C.; Witte, S.; et al. Reductions in Behavioral Deficits and Neuropathology in the R6/2 Mouse Model of Huntington's Disease Following Transplantation of Bone-Marrow-Derived Mesenchymal Stem Cells Is Dependent on Passage Number. Stem Cell Res. Ther. 2015, 6, 9. [CrossRef] [PubMed] 